\title{
The Transformation of Modern Causality in Heidegger's Thought
}

\author{
NERIJUS STASIULIS \\ Department of Philosophy and Cultural Studies, Faculty of Creative Industries, Vilnius Gediminas Technical University, Trakų St. 1, \\ 01132 Vilnius \\ Email:nerijus.stasiulis@vgtu.It
}

\begin{abstract}
The article presents an analysis of the notion of causality in Heideggerian terms. The modern notion of causality presupposes the Cartesian notion of extended space, the principle of sufficient ground (reason), the notion of object as accessible through mathematical description and the notion of linear time. These notions have been critiqued and transformed in Heidegger's thought on Being as unconcealing. Hence the new possibility of conceiving causality as unconcealing - which presupposes another, non-algebraic, notion of space, a temporalized principle of ground, another notion of constant presence and, last but not least, the notion of ecstatic time. The article demonstrates that Heidegger's notion of ecstatic time both implies and presupposes the critique and transformation of the modern notion of causality.
\end{abstract}

Keywords: apriorism, Aristotle, causality, Heidegger, temporality

\section{INTRODUCTION}

Heidegger's ontology has been presented largely in existential terms or in terms of the philosophy of culture. Lithuanian scholars have recently contributed a lot to the field. Sodeika, for instance, has recently (2017) devoted much attention to the Heideggerian notion of boredom and Šerpytyte (2017) has presented a large study on nihilism which owes a lot to her reading of Heidegger, especially the lectures on Nietzsche. The two, alongside D. Bacevičiùtè, co-authored a study (2015) of the transformations in ontology to which Heidegger contributed a great deal. The thought of Šliogeris $(2017,2017$ a), which is also a search for novel ontology, has been shaped by Heidegger's notions of Zuhandenheit and thingness. Sverdiolas (2007) also sought to adapt the notion of Zeug in his Aristotelian-Heideggerian musings on the possibilities of reinterpreting the Western tradition of thought to match current cultural experiences. Kačerauskas, in addition to translating Being and Time (Heidegger 2014), provided a comprehensive overview of key Heideggerian principles and interpretations (Kačerauskas, Vezželis 2016) both in the context of the industry of culture and also with some attention to Heidegger's relation to Aristotle and the Greeks. Most recently, Heidegger's Zeug has been discussed extensively in the context of his philosophy of technology (Mickevičius 2017, 2018; Čapanauskas 2017). ${ }^{1}$

1 Other Lithuanian contributions to the field include Stasiulis (2018), Vabalaite (2017), Véželis (2016), Aleksandravičius (2010), Sodeika (2010), Saldukaitytė (2009), Kačerauskas (2008, 2007, 2006, 2005), Čepulis (2006), Rubavičius (2003), Girnius (2002), Šliogeris (1989). 
This article shall present how the ontological basis of the modern notion of causality has been taken up and transformed in Heidegger's thought. The transformation of the notion of causality is co-dependent on two segments: a transformation of the notion of the principle of ground and a transformation of the notion of time. Accordingly, the article is split into two chapters. The first one shall discuss the way Heidegger's reading of Kant and Aristotle amounts to transforming the principle of ground. The second one shall keep in mind the results presented in the first one and, further, employ Hobbes' formulation of the modern notion of efficient causation to demonstrate that it relies on a 'misreading' of Aristotelian aetiology as well as on the inauthentic notion of time. Thus this article shall exhibit the way Heidegger both destructs the modern notion of causality and retrieves (wieder-holt) the authentic aetiology of ecstatic time.

The modern version of the principle of sufficient ground may be formulated as logical (and atemporal) or as aetiological/causal (and temporal). There is a correspondence between these two formulations in that they both share the antecedent-consequent structure:

antecedent/cause: if/because something (A) exists;

consequent/effect: then/therefore something else than A, (B) must exist.

Both formulations are co-substantiated by the ancient principle of ground, or sub-ject/sub-

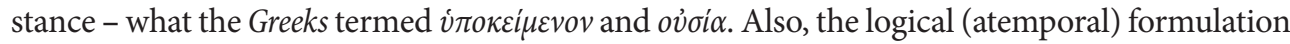
is the more substantial one because, as it has been correctly indicated by thinkers like Spinoza and Bergson, the temporal sequence of causes and effects is, in terms of mechanistic philosophy, in principle pre-given and thus a 'non-being' - a mere illusion with respect to eternity where it exists, as it were, all at once. The two - logical and aetiological - versions of the principle of sufficient reason are equiprimordial and they ground the geometrical (which, in essence, equals deterministic) notion of presence.

Hence, the principle of ground is threefold: first of all, it means 1) substantiality as the ground of an entity, then 2) logicality as the ground of a proposition and 3) causality as the ground of activity. Nevertheless, in all of its three forms, it is dependent (in terms of the history of Being) on the Aristotelian notion of ovoía, or - more generally - of the Greek relevation of Being in terms of constant presence. The Greek unconcealment of Being in terms of constancy of presence is, according to Heidegger, the pre-conceptual source of those notions.

However, the ancient meaning of ovoi $\alpha$ as retrieved by Heidegger is in contradiction with the modern atemporal reading. Hence, the Heideggerian retrieval amounts to an undermining - and a transformation - of the ontological basis of the modern notion of causality. Heidegger accomplishes this huge task by re-reading Aristotle's thinking on ovoí $\alpha$ with the em-

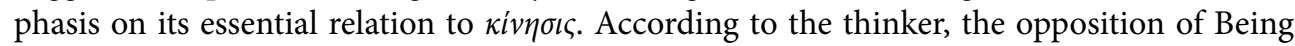
and time and, accordingly, of eternity and temporality was alien to Greek thought which, for this reason, stands in sharp contrast with the modern approach based on Christian heritage. Heidegger aligns his own thought with the Greek one, therefore his rethinking of der Satz vom Grund in a temporal horizon which this article shall present has nothing to do with prioritizing time against timelessness (as in Bergsonian philosophies). Rather, it completely disposes of the duality of 'timelessness' ('eternity') and 'temporality'.

In the following chapters, this article shall exhibit how the Heideggerian notion of Dasein is coincidental with the Heideggerian retrieval of Aristotle's thought and, accordingly, with the Heideggerian critique and transformation of the modern notion of causality. ${ }^{2}$

\footnotetext{
2 The modern paradigm is discussed in Saulius 2016; Stasiulis 2016; Čiurlionis 201; Dumčienė, Saulius 2017.
} 


\section{THE TRANSFORMATION OF THE PRINCIPLE OF GROUND}

\section{The Temporality of Object}

Dasein, as thrown project, understands Being from a temporal horizon. The notion of temporality results from an interpretation of kiv $\sigma / \varsigma$ as a horizon from which $\varphi v \sigma \iota \varsigma$ is thought by Ar-

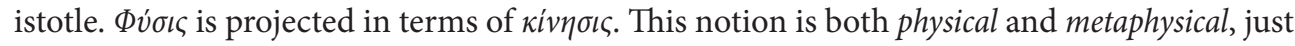

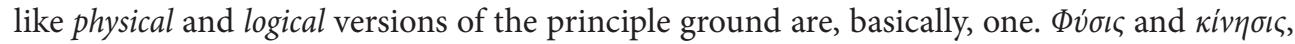
like Being and time, are inseparable, and therefore the principle of ground must be rethought in terms of this temporality of Being.

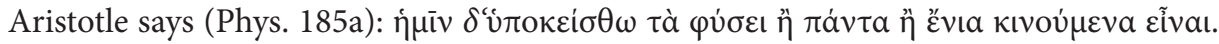
Heidegger renders it as: 'from the outset it should be (a settled issue) for us that those beings that are by $\varphi v i \iota$, whether all of them or some of them [those not in rest], are moving beings (i.e. determined by movedness) (Bewegtheit)' (Heidegger 1998: 186; Heidegger 1979: 243). By 'from the outset' Heidegger indicates the aprioric character of kinesis. As is well-known, Aristotle, in his conception of movement, prioritizes rest. But we must take into account that $\varphi v$ sel óvta 'are in movedness even when they stand still and rest. Rest is a kind of movement; only that which is able to move (das Bewegliche) can rest' (Heidegger1998: 189; Heidegger 1979: 247). Aristotle er-sieht - has an aprioric/metaphysical insight of - kiv $\eta$ $\iota \varsigma$ as crucial in the projection of Being, like, in Heidegger, temporality is the crucial horizon for the understanding of Being. Thus, the issue of movedness is of utmost importance when considering the subject-matter of Physics - $\varphi v$ $\sigma \iota \varsigma$, or Being: 'this means that defining the essence of being is impossible without

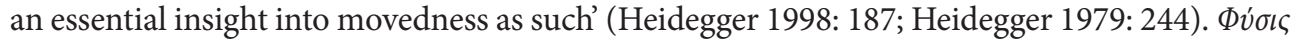

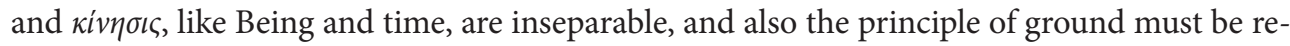
thought in terms of this temporality of Being.

The use of the notion of apriorism is not accidental because Kant's transcendentalism serves, for Heidegger, as the bridge from the Cartesian notion of space/matter/motion and, for that matter, Cartesian dualism in general to the retrieval of original Greek thought. According to Heidegger, Kant's main impact consisted in opening the possibility for a rethinking of identity (the object and the causal relation) by demonstrating the inseparability of a priori forms of the understanding (Verstand) from the a priori forms of sensibility/intuition (Anschaung). Now that understanding had to be united with intuition - and, crucially, with the aprioric form of time - logic, which had been 'atemporal', had to be resubstantiated and transformed (Heidegger 1984: 152-153). Heidegger also does precisely this when he equates Dasein with nous and thinks it in terms of its temporal horizon. Heidegger builds on Kant's notion of schematism to unite sensibility, understanding and reason (which he interprets ontologically as opposed to 'epistemologically') to infuse logic (which since Aristotle has stagnated and has become the basis of cybernetic (informational) causality) with a characteristic of freedom as of temporal unconcealment.

In Heidegger's thought, constant presence is given as a unity of future and past, which is gathered (gesammelt) by Being (ground-less). Identity consists in the unconcealment as in the unity of the three temporal ecstasies. Also, identity is what warrants the object of scientific endeavor: 'If science could not be sure in advance of the identity of its object in each case, it could not be what it is. By this assurance, research makes certain that its work is possible' (Heidegger 1969: 26). The philosophy of Kant has made possible a new consideration of identity, thus, of logic in general and of the object of science. The essential unity of the transcendental 
form of the understanding with the transcendental form of sensibility (of time and of space) meant that identity (object) itself had to be reconsidered from the horizon of time.

This article will now take a closer look at Heideggerian analyses of Kant's philosophy as linking identity (the object of logic and science) with aprioric temporality and of Aristotle's philosophy as giving rise to identity and the principle of ground from the temporal horizon to see how Heidegger moves beyond the principle of ground towards the ontology of Being as Abgrund.

\section{Through Kant to Aristotle to 'Another Thinking'}

According to Kant, the object is conceived when 'the relation [between entities] $<\ldots .>$ is that of "If...then", ("because... therefore")' (Heidegger 1987: 138): 'Because the sun shines, the rock will now become warm', or 'The sun warms the rock' (ibidem: 138). Heidegger calls our attention to the fact that this connection, conceived in terms of the principle of reason (ground), is different from the 'every time when..., then...' connection ('Every time when I see the sun, the stone gets warm') because the latter has to do merely with a 'succession of the perceptions' (ibidem: 138). That is, in the latter case we deal merely with the inauthentic conception of time as of a sequence of moments. Only when the mind captures the constant 'if... - then...' connection, it deals with an object and an eigentlich cognition. The object is grasped by abstracting from the temporal way of conceiving things in terms of a sequence of one after another; but, crucially, the grasp of the object preserves the aprioricity of temporality. Hence, for Heidegger, revealing constant presence is not linked to doing away with temporality but to retaining time as the gathering of the three ecstasies. So the 'if..., then...' connection presupposes the authentic conception of time and for this reason the conception of object can be transformed by demonstrating its origination from the authentic horizon of temporality and its structure.

Thus Heidegger progresses from the philosophy of Kant to the philosophy of Aristotle wherein the (onto)logical principles of identity and non-contradiction were formulated, and he sets on reconstructing its horizon of temporality, or movedness.

As Heidegger presents his phenomenological construal of Aristotle, he claims it to be of utmost importance to understand 'the logic of the grasp of an object' and to raise the issue of 'how an object becomes primordially accessible?' (Heidegger 1994: 20). In the set of lectures on Plato's Sophist he analyses the origin of the grasp of the constant presence (as described in the first book of Aristotle's Metaphysics), he demonstrates that an object becomes available to the agent whose being consists in activity, or movedness, in the interconnectivity of references (Heidegger 2003: 51). At first, the Aristotelian agent, just as the Kantian transcendental subject, discovers among this interconnectivity the 'everytime time when..., then...' connection, which is consequently transformed into the more stable, constant, connection of the 'if..., then.... Thus one progresses from the pre-presentification/presenting (Gegenwärtigen) of performing

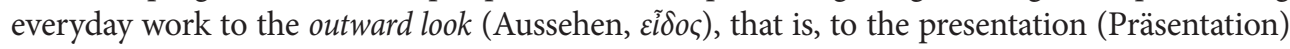
of the insight of essence (ibidem: 51-52; Heidegger 1992: 75). The grasp of (constant) essence arises via the grasp of (temporal) skill ( $\tau \dot{\varepsilon} \chi v \eta)$, hence in the former 'the temporal characters only step into the background; they do not disappear' (Heidegger 2003: 53). And this 'because..., therefore...' ('if..., then...) connection is the connection of ground (reason) and consequence (ibidem: 53). So the connection of ground and consequence (its constant presence) and the interconnectivity of references are in advance inscribed into each other.

It is crucial that the general insight of the constant presence always 'returns' to separate cases, to the presenting of a specific situation. Heidegger's thought both preserves the Greek 
distinction between $\kappa \alpha \theta \dot{\lambda} \lambda o v$ and $\kappa \alpha \theta^{\prime} \dot{\varepsilon} \kappa \alpha \sigma \tau o v$ and emphasizes their unity, which is, as it were, a circle moving from the specific to the general to the specific, etc. It is co-primordialial with the distinction and unity of $\sigma o \varphi i \alpha$ and $\varphi \rho o ́ v \eta \sigma \iota \varsigma$, which in turn have given rise to our traditional distinction between theory and practice. In constrast, involving the grasp of an object into the moving presenting means the Heideggerian unity of practice and theory (see Stasiulis 2016a).

Such is 'the temporal meaning of the way in which circumspect taking care [=moving presenting] becomes modified into the theoretical discovery of things objectively present in the world', referred to in the title of one of the chapters of Being and Time (Heidegger 1996: 322). In the chapter, accordingly, Heidegger demonstrates that the proposition (which corresponds to the object grasped by the mind) originates ontologically from the circumspect (umsichtig) using and working, or from the situative deliberation (Überlegung) which is essential to it, while of this deliberation is characteristic the transcendental schema of 'if..., then...' (Heidegger 2006: 359). This deliberation, or judgment, which is orienting in its circumstances is said to have the existential meaning of Gegenwärtigung, with the Vergegenwärtigung (objectifying, representing as an object) as merely a mode of it (Heidegger 2006: 359). According to Heidegger, this presenting deliberation, of which the if..., then...' schema is characteristic, is only possible because of the view of the whole of Zeug (tools/utensils/useful things) because ' [c]ircumspection moves in the relevant relations of the context of useful things at hand' (Heidegger 1996: 328; Heidegger 2006: 359). This passage illustrates well how by means of Kantian transcendentalism Heidegger's thinking in Being and Time moves from the Kantian insight concerning the temporality of object - by showing the involvement of the 'if..., then...' into the interconnectivity of Zeug (utensils) - to the ontological origin of the concept of cognition in Aristotle (Being and Time is based on a transcendental and phenomenological re-reading of Aristotle).

In Being and Time this interconnectivity is said to be pre-predicative (Heidegger 2006: 359) and hence, possibly, non-thematic. Aristotle's thought is also said to be implicitly based on this interconnectivity. What Heidegger sets up to do is to supply an explicit description of that interconnectivity because his own thought must start in the context of the present-at-hand Cartesian conception which in turn stands on the shoulders of the Greek concept of constant presence. In this precise sense his thought must be considered more fundamental than both the Cartesian and the Aristotelian one because it sets out to show the ontological origin of them both. Being and Time supplies the transcendental basis for the two modes of treating the world and hence the presupposition of a new revelation of Being which later unfolds as 'another thinking.

\section{THE TRANSFORMATION OF THE NOTION OF CAUSE}

\section{Efficient Causality as the Relation of Potency and Act}

Heidegger claims that, in the West, being has always been understood in terms of work (product, creation) (Werk). His notion of Werk coincides with his notion of intentionality. He sees Cartesian ontology as derived from intending constant presence as finished product. Being and Time describes intentionality in terms of working at a product because it allows a consistent transition from a Cartesian (mechanistic) ontology to a non-Cartesian one. The Heideggerian Dasein, especially from the point of view of 'another thinking', means the place where Being unconceals, where it is at work/it produces an $\varepsilon^{\prime} \rho \gamma o v$ - where Kraft, or $\delta v \dot{v} \alpha \mu \iota \varsigma$, puts itself to movement, or work, that is, where $\dot{\varepsilon} v$ - $\dot{\varepsilon} \rho \gamma \varepsilon$ เ $\alpha$ takes place. Hence, the notion of Being, or

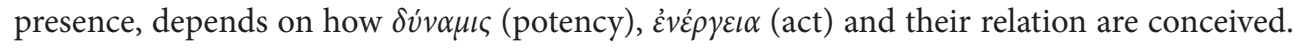


Our analysis of the notion of causality now proceeds by showing how Hobbes' mechanistic philosophy and Heidegger's ontology are both related and differ in that they are two different readings of Aristotelian notion of 'potentiality' - 'actuality'.

What is the relation between the Aristotelian notion of 'potency' and 'act' and the modern notion of causality? This article will treat the modern notion of causality as formulated in Hobbes.

Hobbes takes up the Aristotelian division of causes into c. materialis, c. efficiens, c. formalis, c. finalis but it reduces them to two because, according to him, formal and final causes are but efficient causes (Hobbes 1839: 117). Hobbes says, for instance, that if one first conceives something to be rational ['rationality' is the essence, i.e. the formal cause, of 'man'], then he knows the same to be a man, and therefore it is nothing but efficient cause (ibidem: 117). Thus, for Hobbes, efficient cause is a consequent of an antecedent, the ground of a consequence. For him, the relation of cause (causa) and effect (effectus) is identical to the relation of potentiality (potential) and act (actus): 'Correspondent to cause and effect, are power and act' (Hobbes 1839a; Hobbes 1839: 113).

The Latin version of De Corpore calls these two notions potentia et actus while the original English version names them power and act (Hobbes 1839a: 127) (in accordance with the original sense of Aristotle's $\delta v \dot{v} \alpha \mu \iota \varsigma$ as well as with its Heideggerian translation as Kraft). ${ }^{3}$ The power of the agent (agens) and the efficient cause for Hobbes are the same but considered differently (Hobbes 1839: 113). The power of the agent is also termed active power (potentia activa), while the power of the patient (patientis) - passive power (potentia passiva) (Hobbes 1839: 113-114). The latter corresponds to material cause, with the difference consisting in that causa materialis refers to past tense, while potentia passiva - to future tense. When both - active and passive - powers, or causa efficiens and causa materialis, meet, they form a full or entire (plena or integra) power, or cause, and produce an act (as it is called with respect to power) or an effect (as it is called with respect to cause). 'An entire cause is always sufficient for the production of its effect (ad producendum effectum), if the effect be at all possible' (Hobbes 1839a: 122; Hobbes 1839: 108); cause is the sufficient ground. And every effect has its necessary cause: 'whatsoever effect is produced (productus) at any time, the same is produced by a necessary cause (causa necessaria)' (Hobbes 1839a: 123; Hobbes 1839: 109).

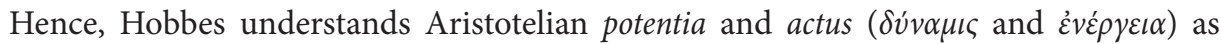
cause and effect and he reduces all four aitia to the principle of sufficient ground (interpreted as efficient causality). Also, this principle of ground is also linked to the inauthentic construal of time in terms of a sequence of nows (which may also be traced back to the treatment of time in Aristotle's Physics). The cause is prior to the effect which it is about to cause, and the effect succeeds the cause. The effect is caused in the very 'same instant, in which the cause is entire' (Hobbes 1839a: 128), but the efficient and the material causes must meet beforehand. Moreover, the English philosopher himself declares that he adheres to the usual conception of time as a sequence - 'for this word time comprehends the notion of former and latter (prius et posterius), or of succession in the motion of a body, in as much as it is first here then there'

3 As some scholars who tend to equate potentiality with mere possibilitas challenge this Heideggerian translation (e.g. Gonzalez 2006), let us note that the Heideggerian translation is in fact based on agelong usage as well as correct. Whereas translating it as possibitas, mere possibility, would mean losing its

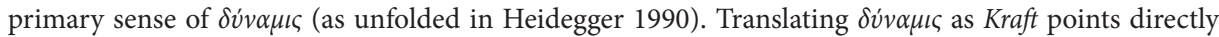
to power as ability and to the origin of the principle of ground from the notion of $\tau \dot{\varepsilon} \chi v \eta$ and $\varepsilon^{\prime} \rho \gamma o v$. It is precisely this meaning which eventually gets lost in the mechanistic-formalistic (logistic and cybernetic, or informational) notion. 
(ibidem: 95; Hobbes 1839: 84) - and adds that his conception 'agrees with the definition of Aristotle, time is the number of motion according to former and latter (Hobbes 1839a: 95), tempus est numerus motus secundum prius et posterius' (Hobbes 1839: 84).

\section{The Destruction of the Modern Notion of Causality}

Heidegger's thought destructs two basic assumptions of modern causality as formulated by Hobbes: the first one is the very notion of efficient cause, and the second one is the related notion of time as a sequence of nows. With the same move, it retrieves the original Aristotelian aetiological notion, while this retrieval 'merges' authentic causality (aetiology) and true temporality.

First of all, Heidegger's philosophy deals with the ontological origin of and with the difference between modern causality and Aristotelian causality. According to the German thinker, causa, casus are related to cadere, to fall, and it means that which brings it about that something 'falls out' as a result, as an effect, and in the modern notion of causality it is precisely the causa efficiens which sets the standard for all causality (Heidegeris 1992b: 222). But this Latin translation of $\alpha_{i \prime \tau}^{\prime} \iota v$ - of being responsible for ('guilty of') something else - does not match the Greek meaning: everything, that was later termed 'causality' and as such sought in Greek thought, in the original realm of Greek thought had nothing to do with bringing about or effecting (ibidem: 222). More precisely, it had nothing to do with deed as actio, from which some result follows - a con-sequence.

In Heidegger's thought, deed/acting/action is understood not as causing a consequence but in the sense of wirken: but the fundamental trait of wirken and Werk does not lie in the words efficere and effectus but in the fact that something is brought to unconcealment (Heidegeris 1992a: 248). Where the Greeks speak of what was in Latin called cause efficiens, stresses Heidegger, they never mean a resulting of an effect (ibidem: 248). What makes the entity in the sense of unconcealing never causes it as an effect of making, like cause efficiens does: Aristotle's doctrine neither uses a corresponding term nor knows the cause termed by it (Heidegeris 1992b: 221). Thus wirken as making (creating) must be understood not in terms of causing an effect but in terms of pro-ducing (her-stellen), bringing into presence (Anwesen) (Heidegger 2000: 43).

Heidegger pays a close attention to the fact that the word tun, do (which means wirken), belongs to the indogermanic root $d h e$, from which also the Greek $\theta \dot{\varepsilon} \sigma \iota \varsigma$ derives. Activity of nature is understood in precisely this meaning of unconcealing: the unfolding of $\varphi v \sigma \iota \varsigma$ (nature) is precisely a doing, in the precise sense of $\theta \dot{\varepsilon} \sigma \iota \varsigma$ (Heidegger 2000: 42). In the primordial Greek thought there was no opposition between $\varphi v \dot{\sigma} \iota \varsigma$ and $\theta \dot{\varepsilon} \sigma \iota \varsigma$ upon which subsequent oppositions of nature and spirit, object and subject, mechanicism and voluntarism are based. For this reason the notion of Dasein, which makes away with both modern Cartesian dualism in general and efficient causality in specific, nears to the Greek notion, or retrieves it.

The same structure of unconcealing (intentionality) ( $\theta \dot{\varepsilon} \sigma ı \varsigma)$ is characteristic of the movement of both 'nature', and Dasein (as 'spirit', or 'Man') (e.g. Heidegger 1992: 247). The analysis of Welt and Umwelt, presented in Being and Time, is by no means an analysis of 'merely' the subjective sphere; it describes $\varphi$ v́бıৎ itself, its Wirklichkeit. This Heideggerian analysis enables one to understand the Aristotelian notion of 'natural' - $\varphi v$ vel - entity (understood in terms of being pro-duced) as of always oriented in a certain direction and having a spatiality which is primordially linked to this orientation - its place as movement upwards or downwards. Heidegger emphasizes that 'direction' is not primarily a 'spatial' concept but rather its meaning of a spatial concept related to the object of 'nature' or geometry derives from an ontologically prior orientation in an environment of - to put it in the words of 'Phenomenological Interpretations of 
Aristotle' - 'factical life' (Heidegger 1994: 144). It is merely in the physical worldview relying on a Cartesian geometric notion of space that 'upwards' and 'downwards' appear as 'subjective' or merely 'relative' while, in fact, they should be conceived in terms of entity as of a pro-duct of the unconcealing of Being, existing in a connectivity of references. ${ }^{4}$

Secondly, Heidegger points out the cognation, through the indogermanic root uerg, of the German Werk and the Greek $\tilde{\varepsilon}$ pyov (Heideger 2000: 44). His Wirklichkeit is the reading of

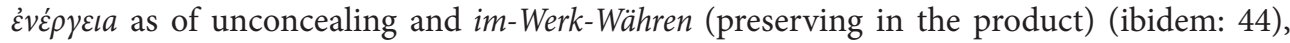
but not as actus which the Romans, like subsequently Hobbes, conceive as a result of operatio. Importantly, making as causing an effect - after the Greek sense has completely blurred - was, in modernity, related to the inauthentic notion of time: 'Eventually, the quest for the relation of cause and effect brings to the fore the one-after-the-other and so the flow of time' (ibidem: 44). While in fact causality as unconcealing acting, or making, must be conceived not in terms of inauthentic time, but as a unity of temporal ecstasies.

Kant's demonstration that temporality as transcendentally a priori paved the way for the Heideggerian reconsidering of the principle of ground and the retrieval of Aristotelian

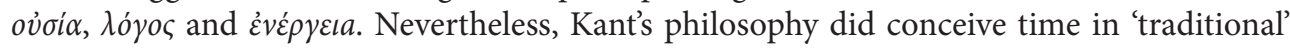
terms, as the now-time, that is, inauthentically. Heidegger keeps pointing out that Kant, just like Hume, 'interprets causality as a rule of succession in time' (ibidem: 44). Therefore Heidegger, as he takes up the Kantian insight into the aprioric character of temporality, also sets on revealing temporality itself in more fundamental terms. As both the grasp of the object and causality are a priori dependent on temporality, the transformation of the notion of temporality is at the time the transformation of the notions of object and causality.

The unity of the temporal ecstasies is a Heideggerian reading of the unity of 'potency'

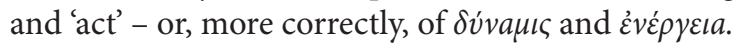

\section{CONCLUSIONS}

Heidegger's 'another thinking' is rooted in the musing on presence as unconcealment which has the structure of the three temporal ecstasies. It leads to a criticism of the modern notion of causality as it has grown out of the inauthentic understanding of presence coupled with the inauthentic understanding of temporality. On the other hand, authentic presence and authentic temporality are identical to each other. In order to get to the bottom of presence as unconcealment, Heidegger has to go back to the Greek thought - where he pays a special attention to Aristotle's thought and his aetiology. The retrieval of this aetiology amounts to undermining the ontological basis of the modern notion of causality as well as to the contour of Heidegger's own ontology of presence.

Received 11 November 2018 Accepted 5 February 2018

\section{References}

1. Aleksandravičius, P. 2010. „Heideggerio jaunystės filosofija: nuo amžinybės garbinimo iki laiko suabsoliutinimo“, Logos 67: 23-36.

2. Aristotelēs. 1837. "Fusikē Akroaseōs. Ex. Rec. I. Bekker”, in Aristoteles Graece, Volumen Prius. Bernolini: Apud Georgium Reimerum.

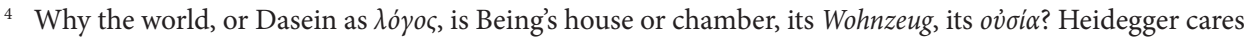
to reveal a possibility of an authentic unconcealing of Being which is not based on Cartesian metaphysics. The (post-)Cartesian scientific endeavour is not rejected but, rather, preserved while also transforming its metaphysical basis. 
3. Čapanauskas, T. 2017. "Dvejopa machinacijos samprata Heideggerio technikos filosofijoje”, Problemos 92: 169-179.

4. Čepulis, N. 2006. „Ontologijos fundamentalumo klausimas; Levinas ir Heideggeris“, Athena 2: 173185.

5. Čiurlionis, J. 2017. “On Identity and Simultaneity”, Filosofija. Sociologija 28(3): 165-171.

6. Dumčienè, A.; Saulius, T. 2017. "From Cosmos to Chaos: Philosophical Aspects of Paradigm Shift”, Filosofija. Sociologija 28(1): 65-72.

7. Girnius, J. 2002. Heideggerio egzistencialines filosofijos pagrindai. Kaunas: VDU leidykla.

8. Gonzalez, F. J. 2006. "Whose Metaphysics of Presence? Heidegger's Interpretation of Energeia and Dunamis in Aristotle", Southern Journal of Philosophy 44(4): 533-568.

9. Heidegger, M. 1969. "The Principle of Identity", in Martin Heidegger. Identity and Difference. Transl. by J. Stambaugh. New York, Evanston, London: Harper \& Row Publishers.

10. Heidegger, M. 1979. "Vom Wesen und Begriff des Фúбıৎ, Aristoteles, Physik B, 1 (1939)", in Martin Heidegger. Gesamtausgabe. I. Abteilung: Veröffentlichte Schriften 1917-1970. Bd. 9: Wegmarken. Frankfurt am Main: Vittorio Klostermann.

11. Heidegger, M. 1984. "Die Frage nach dem Ding. Zu Kants Lehre von den Transzendentalen Grundsätzen”, in Martin Heidegger. Gesamtausgabe. II. Abteilung: Vorlesungen 1923-1944. Band 41: Die Frage nach dem Ding. Zu Kants Lehre von den Transzendentalen Grundsätzen. Frankfurt am Main: Vittorio Klostermann.

12. Heidegger, M. 1987. What is a Thing? Transl. by W. B. Barton, Jr. and V. Deutch. South Bend, Indiana: Gateway Editions, Ltd.

13. Heidegger, M. 1990. “Aristoteles, Metaphysik $\Theta 1$ 1-3, Von Wesen und Wirklichkeit der Kraft”, in Martin Heidegger. Gesamtausgabe. II. Abteilung: Vorlesungen 1923-1944. Bd. 33: Aristoteles, Metaphysik $\Theta$ 1-5, Von Wesen und Wirklichkeit der Kraft. Frankfurt am Main: Vittorio Klostermann.

14. Heidegger, M. 1992. "Platon: Sophistes", in Martin Heidegger. Gesamtausgabe. II. Abteilung: Vorlesungen 1919-1944. Bd. 19: Platon: Sophistes. Frankfurt am Main: Vittorio Klostermann.

15. Heidegger, M. 1994. "Phänomenologische Interpretationen zu Aristoteles. Einführung in die phänomenologische Forschung (Winter semester 1921/22)", in Martin Heidegger. Gesamtausgabe. II. Abteilung: Vorlesungen. Bd. 61. Vorträge und Aufsätze. Frankfurt am Main: Vittorio Klostermann.

16. Heidegger, M. 1996. Being and Time. Transl. by J. Stambaugh. State University of New York Press.

17. Heidegger, M. 1998. “On the Essence and Concept of Фúrıৎ in Aristotles' Physics B, 1 (1939)”, in Martin Heidegger, Pathmarks, ed. W. McNeill. Cambridge: Cambridge University Press.

18. Heidegger, M. 2000. "Wissenschaft und Besinnung", in Martin Heidegger. Gesamtausgabe. I. Abteilung: Veröffentlichte Schriften 1910-1976. Bd. 7. Vorträge und Aufsätze. Frankfurt am Main: Vittorio Klostermann.

19. Heidegger, M. 2003. Plato's Sophist. Transl. by R. Rojcewicz and A. Schuwer. Indiana University Press.

20. Heidegger, M. 2006. Sein und Zeit. Tübingen: Max Niemeyer Verlag.

21. Heidegger, M. 2014. Bütis ir laikas. Vert. T. Kačerauskas. Vilnius: Technika.

22. Heidegeris, M. 1992. „Metafizikos įveika“, iš Martynas Heidegeris. Rinktiniai raštai, vert. A. Šliogeris. Vilnius: Mintis.

23. Heidegeris, M. 1992a. „Mokslas ir apmąstymas“, iš Martynas Heidegeris. Rinktiniai raštai, vert. A. Šliogeris. Vilnius: Mintis.

24. Heidegeris, M. 1992b. „Technikos klausimas“, iš Martynas Heidegeris. Rinktiniai raštai, vert. A. Šliogeris. Vilnius: Mintis.

25. Hobbes, Th. 1839. "Elementorum philosophiae sectio prima De corpore", in Thomae Hobbes Malmesburiensis opera philosophica, quae latine scripsit, omnia in unum corpus nunc primum collecta studio et labore Gulielmi Molesworth. Vol. I. Londini: Apud Joannem Bohn, MDCCCXXXIX.

26. Hobbes, Th. 1839a. "Elements of Philosophy. The First Edition, Concerning Body, written in Latin by Thomas Hobbes of Malmesbury, and translated into English", in The English Works of Thomas Hobbes of Malmesbury; Now First Collected and Edited by Sir William Molesworth, Bart. Vol. I. London: John Bonn, MDCCCXXXIX.

27. Kačerauskas, T. 2005. „Kultūros filosofija ir egzistencinè fenomenologija“, Problemos 68: 32-40.

28. Kačerauskas, T. 2006. Filosofiné poetika. Vilnius: Versus aureaus.

29. Kačerauskas, T. 2007. „Laikas ir erdvè: Aristotelis, Kantas, Heideggeris“, Logos 53: 45-55.

30. Kačerauskas, T. 2008. Tikrove ir kūryba: kultūros fenomenologijos metmenys. Vilnius: Technika.

31. Kačerauskas, T.; Věželis, T. 2016. Šiapusybès regionai: 50 Heideggerio filosofijos klausimų. Vilnius: Technika. 
32. Mickevičius, T. N. 2017. Graikiškosios gaminimo sampratos apmastymas Heideggerio technikos filosofjoje. Vilnius: Vilniaus universiteto leidykla.

33. Mickevičius, T. N. 2018. "Heidegger's Twofold Treatment of Modern Technology", Filosofija. Sociologija 29(1): $32-38$.

34. Rubavičius, V. 2003. Postmodernusis diskursas: filosofine hermeneutika, dekonstrukcija, menas. Vilnius: Kultūros, filosofijos ir meno institutas.

35. Saldukaitytė, J. 2009. „M. Heideggeris ir pagrindinès fenomenologijos problemos: ontologinis skirtumas", Problemos 76: 99-111.

36. Saulius, T. 2016. "Philosophical Method and Science", Filosofija. Sociologija 27(1): 31-39.

37. Sodeika, T. 2010. Filosofija ir tekstas. Kaunas: Technologija.

38. Sodeika, T.; Šerpytyte, R.; Bacevičiūte, D. 2015. Ontologijos transformacijos: medijos, nihilizmas, etika. Vilnius: Vilniaus universiteto leidykla.

39. Sodeika, T. 2017. Kasdienybes fenomenologija: nuobodulys. Presentation at the scholarly conference "KASdienybès vertybiniai aspektai" held by the Lithuanian Academy of Sciences Department of Humanities and Social Sciences, Lithuanian Center for Social Research, Vilnius Gediminas Technical University Faculty of Creative Industries and Lithuanian Association of Communication. Available at: http://www.youtube.com/watch?v=6A3Mp9aVh_c\&t=696s

40. Stasiulis, N. 2016. "On the Conception of the Creative in Natural Science and Philosophical Reflections Thereof”, Creativity Studies 9(1): 42-52.

41. Stasiulis, N. 2016a. "On the Unity of Theory and Practice in Heidegger's Thought", Filosofija. Sociologija 27(2): 249-256.

42. Stasiulis, N. 2018. “The Everyday in Heidegger's Revolutionary Thought", Filosofija. Sociologija 29(3): 176-184.

43. Sverdiolas, A. 2007. "Darbas ir dirbinys. Aristotelinis heidegerinis svarstymas", Problemos 72: 87-95.

44. Šerpytytè, R. 2007. Nihilizmas ir Vakaru kultūra: mokslinè monografija. Vilnius: Vilniaus universiteto leidykla.

45. Šliogeris, A. 1989. Žmogaus pasaulis ir egzistencinis mastymas. Vilnius: Vilniaus universiteto leidykla.

46. Šliogeris, A. 2017. Daiktas ir menas: du meno kürinio ontologijos etiudai. Vilnius: Margi raštai.

47. Šliogeris, A. 2017a. Niekis ir Esmas, I ir II tomai. Vilnius: Apostrofa.

48. Vabalaite, R. M. 2017. "The Activity and Passivity in the Creation of Art: Heidegger and Later Philosophers", Filosofija. Sociologija 28(1): 3-10.

49. Vèželis, T. 2016. „Čiabūties (Dasein) egzistencinių (existenziell) ir egzistencialiụjų (existenzial) apriorinių struktūrų analizè M. Heideggerio veikale Bütis ir laikas", Filosofija. Sociologija 3: 257-265.

\title{
Moderniojo priežastingumo transformacija M. Heideggerio mąstyme
}

\begin{abstract}
Santrauka
Straipsnyje pateikiama heidegeriška priežastingumo sampratos analizè. Modernioji priežastingumo samprata remiasi karteziškąja tịsios erdvès samprata, pakankamo pagrindo principu, matematiniu aprašymu prieinamo objekto samprata ir linijinio laiko samprata. M. Heideggeriui mąstant apie būtị kaip išslaptinimą, šios sampratos buvo kritiškai aptartos ir transformavosi. Todèl kilo nauja galimybė suvokti priežastingumą kaip išslaptinimą - o šis numato kitą, ne algebrinę, erdvés sampratą, pagrindo principo temporalizaciją, kitokią nekintančio esmo sampratą ir, žinoma, ekstatinio laiko sampratą. Parodoma, kad heidegeriškoji ekstatinio laiko samprata ir kyla iš moderniosios priežastingumo sampratos kritikos bei transformacijos.
\end{abstract}

Raktažodžiai: apriorizmas, Aristotelis, Heideggeris, laikiškumas, priežastingumas 